\title{
Effects of Fasting and Feeding on
}

\section{Protein Synthesis by the Rat Pancreas}

\author{
J. A. Morisset and P. D. Webster \\ From the Section of Gastroenterology, Veterans Administration Hospital and \\ Medical College of Georgia, Augusta, Georgia 30904
}

\begin{abstract}
A в S T R A C T These experiments were designed to determine whether fasting and feeding were associated with differing rates of protein synthesis in the rat pancreas. It has been established that feeding, acetylcholine, or cholecystokinin-pancreozymin administration was associated with enhanced rates of digestive enzyme secretion; however, the literature is unclear as to effects of such stimulation on enzyme synthesis. Rats fed ad lib. or fasted 24,48 , or $72 \mathrm{hr}$ were used for this study. Pancreases were removed and incubated in tissue culture medium with $\mathrm{L}$-phenylalanine ${ }^{14} \mathrm{C}$, and incorporation into TCA-insoluble material as well as purified amylase was measured. Compared with fed controls, fasting 24 , 48 , and $72 \mathrm{hr}$ was associated with $29 \%, 39 \%$, and $35 \%$ decreases in incorporation of $\mathrm{L}$-phenylalanine- ${ }^{14} \mathrm{C}$ into protein. Decreases of similar magnitudes were apparent whether the data were expressed in terms of protein or DNA. Pancreatic amylase isolated from rats fasted $48 \mathrm{hr}$ contained $57 \%$ fewer counts of L-phenylalanine${ }^{14} \mathrm{C}$ than amylase isolated from fed rats. Moreover, rats fasted for $24 \mathrm{hr}$ and given bethanechol chloride incorporated greater amounts of L-phenylalanine- ${ }^{14} \mathrm{C}$ into protein than fasted controls. Studies were performed to exclude changes in pool size of precursor ( $\mathrm{L}$-phenylalanine $-{ }^{14} \mathrm{C}$ ) or product (amylase) in accounting for decreases associated with fasting. These studies demonstrate that fasting was associated with decreased rates of pancreatic amylase and protein synthesis in rats.
\end{abstract}

\section{INTRODUCTION}

Current literature is unclear as to whether fasting or feeding is associated with changes in rates of protein synthesis in the mammalian pancreas. One group of investigators studying rats and pigeons found protein synthesis to be increased after pancreatic stimulation by

Received for publication 10 March 1971 and in revised form 26 July 1971. feeding or administration of cholinergic drugs and pancreozymin (1-4). Another group of investigators found protein synthesis to be constant and not increased after pancreatic stimulation by feeding or administration of cholinergic drugs and pancreozymin (5-8). Resolution of this question seems basic to an understanding of acinar cell function, for if feeding is associated with increases in pancreatic enzyme synthesis, then it is reasonable to inquire as to the mechanisms whereby such increases are obtained. These experiments were performed to determine whether rates of protein synthesis in the rat pancreas were changed by fasting or feeding.

Pancreatic protein and amylase synthesis have been examined in rats which were fed, fasted, or fasted and given bethanechol. The results show that pancreases obtained from fed rats incorporated greater amounts of L-phenylalanine $-{ }^{14} \mathrm{C}$ into tissue proteins and amylase than pancreases from fasted rats. These differences were apparent whether results were expressed in terms of counts per minute/milligram protein or milligrams DNA. Moreover, pancreatic microsomes prepared from fed rats incorporated greater amounts of L-phenylalanine${ }^{14} \mathrm{C}$ into protein in vitro than microsomes prepared from fasted rats. Enhancement of protein synthesis by pancreases from fed rats could not be accounted for by changes involving pool size of either precursor or product. The results show that protein synthesis in the rat pancreas is variable and that it is increased after feeding or bethanechol administration. The precise mechanisms whereby these two different processes are controlled and integrated remains a problem for future investigation.

\section{METHODS}

Male Sprague-Dawley rats $(250-300 \mathrm{~g})$ maintained on Purina Rat Chow (Ralston Purina Co., St. Louis, Mo.) were used for all studies. Rats referred to as "fasted" were denied food for 24,48 , or $72 \mathrm{hr}$; rats referred to as "fed" had free access to food. All rats had free access to water. 
The following materials were used: L-phenylalanine- ${ }^{14} \mathrm{C}$ $(0.37 \mathrm{mCi} / \mu$ mole) uniformly labeled (UL) (New England Nuclear Corp., Boston, Mass.; bethanechol chloride (Merck Sharp \& Dohme, West Point, Pa.) ; materials for tissue culture media, NCTC-109, MEM, 100X, (Microbiological Associates, Inc., Bethesda, Md.) ; calf thymus deoxyribonucleic acid (DNA) and pancreatic alpha amylase (Worthington Biochemical Corp., Freehold, N. J.) ; hydroxymethylaminomethane (Tris) and orcinol (Fisher Scientific Company, Pittsburgh, Pa.); ultrafiltration cell model 402 and Diaflo Membranes PM-10 (Amicon Corp., Lexington, Massachusetts); diethylaminoethyl cellulose (DE-52) and carboxymethylcellulose (CM-52) (Scientific Division, Reeve Angel, Clifton, N. J.) ; Sephadex G-75 and G-100 (Pharmacia, Uppsala, Sweden); diphenylamine (Eastman Organic Chemical, Rochester, N. Y.) ; D-ribose (Nutritional Biochemical Corporations, Cleveland, Ohio) ; and bovine serum albumin (crystallized and lyophilized) (Sigma Chemical Co., St. Louis, Mo.).

Treatment of tissue. Rats were killed by decapitation, pancreases removed, fat and excess tissue trimmed, and the tissue weighed on a Roller-Smith balance and then placed in ice-cold freshly oxygenated Krebs-Ringer phosphatebuffered solution, $\mathrm{pH}$ 7.4. In vitro incubations were performed in 25-ml Erlenmeyer flasks placed in a shaking water bath $(80$ strokes $/ \mathrm{min})$ at $37^{\circ} \mathrm{C}$ under oxygen $(100$ $\mathrm{mg}$ pancreas $/ 1 \mathrm{ml}$ tissue culture medium). The tissue culture medium was prepared by mixing $50 \mathrm{ml}$ of NCTC-109, 10 $\mathrm{ml}$ nonessential amino acids, $21.2 \mathrm{mg}$ calcium chloride, $1.9 \mathrm{~g}$ glucose in 1 liter Krebs-Ringer phosphate-buffered $(0.01 \mathrm{M}$, $\mathrm{pH} 7.4$ ) solution. The concentration of $\mathrm{L}$-phenylalanine in this medium was $48 \mu \mathrm{M}$ to which was added $0.02 \mu \mathrm{Ci}$ $\mathrm{L}$-phenylalanine- ${ }^{14} \mathrm{C}$. The incubation medium was oxygenated immediately before use.

Studies of L-phenylalanine $-{ }^{14} \mathrm{C}$ incorporation into tissue proteins. For incorporation studies, rats were either fed ad lib. or fasted 24,48 , or $72 \mathrm{hr}$. For studies examining effects of bethanechol chloride, rats fasted $48 \mathrm{hr}$ were given either bethanechol chloride (2 $\mathrm{mg} / \mathrm{kg}$ subcutaneous [s.c.]) or saline and killed 60 min later.

Studies of phenylalanine $-{ }^{14} \mathrm{C}$ incorporation into microsomal protein by rat pancreas. For these studies, rats were fed ad lib. or fasted 24,48 , and $72 \mathrm{hr}$. The animals were killed, and the pancreases removed and prepared as previously described. Whole pancreases were incubated at $37^{\circ} \mathrm{C}$ for 15 min in tissue culture medium $(100 \mathrm{mg} / 1 \mathrm{ml}$ medium per $0.1 \mu \mathrm{Ci}$ L-phenylalanine $-{ }^{14} \mathrm{C}$ ). At completion of incubation, the supporting medium was aspirated, and tissue was washed quickly twice with ice-cold medium and then passed through a tissue press. The tissue was homogenized using a Teflon homogenizer ( 8 passes at $500 \mathrm{rpm}$ ) in $0.44 \mathrm{M}$ sucrose $(1 \mathrm{~g}$ tissue $/ 10 \mathrm{ml}$ sucrose). The homogenate was centrifuged $2500 \mathrm{rpm}$ for $10 \mathrm{~min}$ (twice). The supernate was centrifuged at $11,000 \mathrm{rpm}$ for $15 \mathrm{~min}$ (twice), and the resulting supernate was centrifuged at $43,000 \mathrm{rpm}$ for $90 \mathrm{~min}$ in an L2-65 Beckman preparative centrifuge (50 rotor) (Beckman Instruments, Inc., Fullerton, Calif.). The supernate from the high-speed centrifugation was decanted, and the pellet was washed twice by swirling with $1 \mathrm{ml} 0.44 \mathrm{M}$ sucrose and resuspended in $2 \mathrm{ml}$ of $2.1 \mathrm{~N}$ perchloric acid. The precipitate was washed twice with perchloric acid, once with $95 \%$ ethanol, and twice with ether-ethanol mixture. The precipitate was solubilized in $0.5 \mathrm{~N}$ potassium hydroxide; protein and RNA were measured as described.

Studies of L-phenylalanine $-{ }^{14} \mathrm{C}$ incorporation into amylase. Two separate experiments were performed; each experi- ment used 10 rats, 5 fed ad lib. and 5 fasted $48 \mathrm{hr}$. The animals were killed, and pancreases were removed and incubated in tissue culture medium as described. Upon completion of in vitro incubation, pancreases of similar groups were pooled, supporting media aspirated, and tissue washed two times with ice-cold $0.02 \mathrm{M}$ potassium phosphate buffer $(\mathrm{pH} 8.0)$. The pancreases were then suspended in $12 \mathrm{cc}$ of $0.02 \mathrm{M}$ potassium phosphate buffer $(\mathrm{pH} 8.0)$ and homogenized using a ground glass tissue grinder. Soybean trypsin inhibitor $(50 \mathrm{mg}$ ) was added to the homogenate, and the homogenate was dialyzed overnight against 5 liters of 0.02 м potassium phosphate buffer $(\mathrm{pH} 8.0)$. The retentate was centrifuged again at $15,000 \mathrm{rpm}$ for $15 \mathrm{~min}$. The supernate was placed on a Sephadex G-75 column $(45 \mathrm{~cm} \times 2.5$ $\mathrm{cm})$ coupled to a DEAE-52 column $(30 \mathrm{~cm} \times 1.5 \mathrm{~cm})$. Proteins were eluted with $0.02 \mathrm{M}$ potassium phosphate buffer $(\mathrm{pH} 8.0)$. The eluent containing amylase activity was reduced to a $10 \mathrm{ml}$ volume by ultrafiltration. The sample was then placed on a Sephadex G-100 column $(45 \mathrm{~cm} \times 2.5 \mathrm{~cm})$, and proteins were eluted with $0.02 \mathrm{~m}$ potassium phosphate buffer ( $\mathrm{pH} 8.0)$. The eluent containing maximal amylase activity was concentrated and dialyzed by ultrafiltration against $450 \mathrm{ml} 0.005 \mathrm{M}$ potassium phosphate buffer $(\mathrm{pH}$ $6.2)$. The retentate $(10 \mathrm{ml})$ was applied to a carboxymethyl-cellulose $(\mathrm{CM}-52)$ column $(12 \mathrm{~cm} \times 1.5 \mathrm{~cm})$. Proteins were eluted with $0.005 \mathrm{M}$ potassium phosphate buffer ( $\mathrm{pH}$ 6.2) and a linear gradient of $\mathrm{NaCl}(0.0-0.45 \mathrm{M})$. The eluent was concentrated by ultrafiltration; amylase activity, protein content, and radioactivity were then determined.

Studies of L-phenylalanine ${ }^{14} \mathrm{C}$ incorporation by rat pancreatic microsomes. Six fasted (48 hr) or fed rats were used in each experiment. The pancreases were homogenized $(10 \% \mathrm{w} / \mathrm{v})$ in $0.44 \mathrm{M}$ sucrose with a Teflon homogenizer (0.004 in. clearance, 8 passes, $500 \mathrm{rpm})$. The homogenate was centrifuged at $2500 \mathrm{rpm}(10 \mathrm{~min})$, supernate centrifuged at $11,000 \mathrm{rpm}(15 \mathrm{~min})$, and resultant supernate centrifuged at $65,000 \mathrm{rpm}$ (30 min) using a Spinco L2-65B ultracentrifuge (Rotor 65). A common pooled supernatant fraction was used as a source for activating enzymes. The microsomal pellet was washed twice and resuspended in $0.25 \mathrm{M}$ sucrose $(0.5 \mathrm{ml} / \mathrm{g}$ tissue wet $\mathrm{wt})$. Microsomes were incubated for $10 \mathrm{~min}$ at $37^{\circ} \mathrm{C}$ with an energy-generating system as described by Redman, Siekewitz, and Palade (9). Radioactivity and protein were measured. Results were expressed as counts per minute/milligram microsomal protein.

Studies of amino acid content. Two experiments were performed to measure free amino acid content of pancreases from rats fed or fasted $48 \mathrm{hr}$. Pancreases from three animals were pooled, homogenized in $1 \%$ picric acid, centrifuged, and excess picric acid removed from the supernate by passage through a Dowex $2-\mathrm{X} 10$ column. The samples were lyophilized, buffered to $\mathrm{pH} 2.2$, and stored at $-20^{\circ} \mathrm{C}$ until time of assay. Amino acids were assayed by the technique of Spackman, Stein, and Moore using a Beckman 120-B amino acid autoanalyzer (10). These methods have been used previously (11).

Studies of $\mathrm{L}$-phenylalanine- ${ }^{14} \mathrm{C}$ accumulation by rat pancreas. 15 fasted ( $48 \mathrm{hr}$ ) and 15 fed rats were used in each experiment; the pancreases were incubated in tissue culture medium (100 $\mathrm{mg} \mathrm{TWW} / \mathrm{ml}$ medium) containing $0.02 \mu \mathrm{Ci} / \mathrm{ml} \mathrm{L}$-phenylalanine $-{ }^{14} \mathrm{C}$ for $5,10,20,30$, and 60 min. At completion of incubation, the tissue was removed from medium, blotted quickly on filter paper, and homogenized in 5\% TCA. Radioactivity was measured in the media, precipitable (protein) and nonprecipitable (soluble) 
TABLE I

Effects of Fasting and Feeding on L-Phenylalanine-14C Incorporation into Protein by Rat Pancreas

\begin{tabular}{lccccccc}
\hline $\begin{array}{c}\text { Fed or } \\
\text { fasted }\end{array}$ & $\begin{array}{c}\text { No. } \\
\text { of } \\
\text { rats }\end{array}$ & L-phenylalanine-14C & $P$ value & $\begin{array}{c}\% \\
\text { difference }\end{array}$ & L-phenylalanine-14C & $P$ value & $\begin{array}{c}\% \\
\text { difference }\end{array}$ \\
\hline & & $c p m / m g$ protein & & & $c p m / 100 \mu g ~ D N A$ & & \\
Fed & 6 & $17,661 \pm 753$ & & & $39,251 \pm 1912$ & & $29 \%$ \\
Fasted $24 \mathrm{hr}$ & 6 & $14,483 \pm 793$ & $<0.01$ & $18 \%$ & $27,807 \pm 1111$ & $<0.01$ & $34 \%$ \\
Fasted $48 \mathrm{hr}$ & 6 & $13,866 \pm 1008$ & $<0.02$ & $21 \%$ & $25,757 \pm 1824$ & $<0.001$ & $35 \%$ \\
Fasted 72 hr & 6 & $12,742 \pm 743$ & $<0.001$ & $28 \%$ & $25,671 \pm 1285$ & $<0.001$ & 350 \\
\hline
\end{tabular}

Values are means \pm SE. Fed or fasted rats were studied. Pancreases were incubated in 25-ml Erlenmeyer flasks containing tissue culture media $\left(100 \mathrm{mg}\right.$ tissue $/ 1 \mathrm{ml}$ media) and L-phenylalanine- ${ }^{14} \mathrm{C}$. Incubation was performed in a shaking water bath under oxygen at $37^{\circ} \mathrm{C}$ for $60 \mathrm{~min}$. Reaction was stopped by addition of 1 volume of $10 \%$ TCA and incorporation into protein determined.

fractions of the tissue. These methods have been used previously (11).

Preparation of protein for counting. Precipitates were washed four times with vigorous stirring in $5 \mathrm{ml}$ of $10 \%$ trichloracetic acid containing unlabeled L-phenylalanine. The precipitate was then extracted with hot TCA, washed once with $95 \%$ ethanol and twice with ether-ethanol (3:1). At completion of the washing procedure, the precipitate was dissolved in $3 \mathrm{ml}$ of $0.5 \mathrm{~N} \mathrm{KOH}$ and heated at $90^{\circ} \mathrm{C}$ for 20 min. Samples of this solution were placed in glass counting vials along with $10 \mathrm{ml}$ of scintillation mixture, and radioactivity was determined as previously described (11).

Protein was assayed by either the biuret (12) or Lowry, Rosebrough, Farr, and Randall method (13). Amylase activity was assayed by the Bernfeld method using lintner starch as substrate (14). A unit of amylase activity represents that amount which catalyzes the formation of $1 \mathrm{mg}$ of maltose from starch in $3 \mathrm{~min}$ at $37^{\circ} \mathrm{C}$. RNA and DNA were separated by modifications of methods described by Schneider and Schmidt and Tannhauser (15-17). RNA was assayed by the orcinol method using ribose as the standard; DNA was assayed by the diphenylamine method using calf thymus DNA as the standard (18).

\section{RESULTS}

Table I shows effects of feeding and fasting on L-phenylalanine- ${ }^{14} \mathrm{C}$ incorporation into tissue protein by rat pancreas incubated in vitro. Compared with fed rats, fasting for 24,48 , and $72 \mathrm{hr}$ was associated with an $18 \%, 21 \%$, and $28 \%$ decrease in L-phenylalanine ${ }^{14} \mathrm{C}$ incorporation into protein per milligram protein. When the data were expressed as $\mathrm{cpm}$ in protein $/ 100 \mu \mathrm{g}$ DNA, fasting 24, 48, and $72 \mathrm{hr}$ was associated with a $29 \%, 39 \%$, and $35 \%$ decrease in incorporation. Differences between fed and fasted animals were statistically significant.

Fig. 1 shows rates of L-phenylalanine ${ }^{14} \mathrm{C}$ incorporation into tissue proteins by pancreatic tissue obtained from rats fed ad lib. or fasted $48 \mathrm{hr}$. Incorporation, expressed as $\mathrm{cpm} / \mathrm{mg}$ protein or $\mathrm{cpm} / 100 \mu \mathrm{g}$ DNA, was linear for periods of incubating ranging from 10 to $120 \mathrm{~min}$. For all time periods studied, fed rats showed greater incorporation of $\mathrm{L}$-phenylalanine- ${ }^{14} \mathrm{C}$ into protein than fasted ones.

Table II shows effects of feeding and fasting on phenylalanine $-{ }^{14} \mathrm{C}$ incorporation into microsomal protein by whole pancreas incubated in vitro for 15 min. These experiments utilizing short periods of in vitro incubation as well as examining incorporation into microsomal proteins were performed to minimize effects of changes in pool size of product (protein), which might be associated with feeding or fasting. The table shows that pancreases from animals fasted 24,48 , and $72 \mathrm{hr}$ incorporated fewer counts into protein when the data were expressed in terms of counts per minute incorporated into protein per milligram protein or milligram RNA. The increased incorporation $(+8 \%)$ into protein per milligram RNA found in the

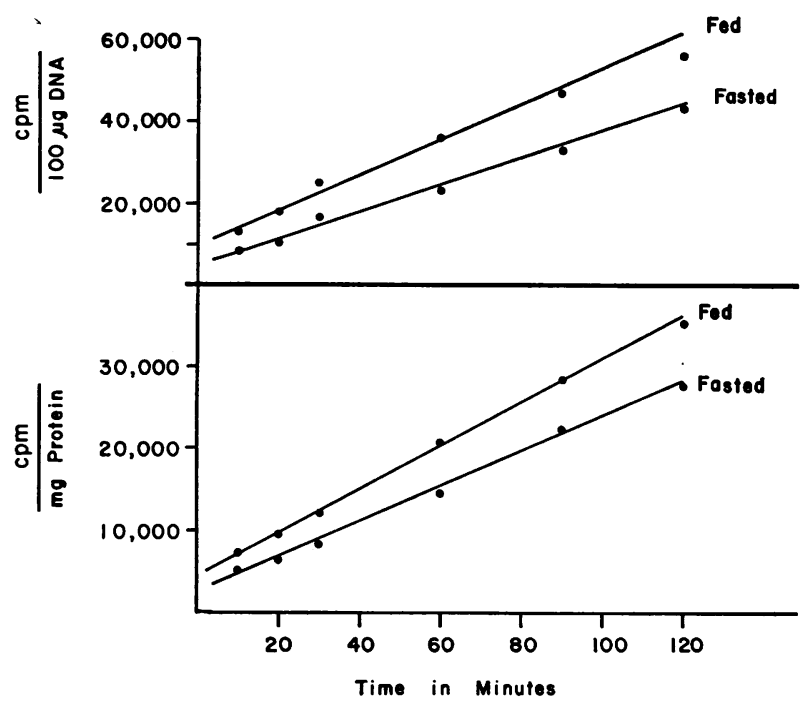

Figure 1 Rate of L-phenylalanine- ${ }^{14} \mathrm{C}$ incorporation by pancreases from rats fed ad lib. or fasted $48 \mathrm{hr}$. Data expressed in terms of incorporation into protein per $100 \mu \mathrm{g}$ DNA (top) or mg protein (bottom). 
TABLE II

Effects of Fasting and Feeding on L-Phenylalanine-14C Incorporation into Microsomal Protein

\begin{tabular}{|c|c|c|c|c|c|c|c|c|}
\hline Treatment & $\begin{array}{l}\text { No. } \\
\text { of } \\
\text { exp. }\end{array}$ & $\begin{array}{l}\text { L-phenyl- } \\
\text { alanine-14 } \mathrm{C}\end{array}$ & $P$ value & $\begin{array}{c}\% \\
\text { difference }\end{array}$ & $\begin{array}{l}\text { L-phenyl- } \\
\text { alanine-14 }\end{array}$ & $P$ value & $\begin{array}{c}\% \\
\text { difference }\end{array}$ & $\frac{\text { mg protein }}{\text { mg RNA }}$ \\
\hline & & $\begin{array}{c}c p m / m g \\
\text { protein }\end{array}$ & & & $c p m / m g R N A$ & & & \\
\hline Fed ad lib. & 3 & 10,563 & & 一 & 90,073 & & 一 & 9.7 \\
\hline Fasted $24 \mathrm{hr}$ & 4 & 8,445 & NS & $-20 \%$ & 97,724 & NS & $+8 \%$ & 11.3 \\
\hline Fasted $48 \mathrm{hr}$ & 4 & 5,945 & $<0.025$ & $-44 \%$ & 65,120 & $<0.050$ & $-28 \%$ & 11.0 \\
\hline Fasted $72 \mathrm{hr}$ & 3 & 4,334 & $<0.010$ & $-59 \%$ & 48,624 & $<0.050$ & $-46 \%$ & 10.1 \\
\hline
\end{tabular}

Values are means. Fed or fasted rats studied. Pancreases were incubated for $15 \mathrm{~min}$ in tissue culture medium containing L-phenylalanine- ${ }^{-14} \mathrm{C}$. At completion of incubation, the medium was aspirated, the tissue homogenized, and a microsomal pellet prepared by centrifugation. Data expressed as cpm in protein/mg protein and cpm in protein/mg RNA. RNA expressed as RNA-ribose.

$24 \mathrm{hr}$ fasted groups while reproducible was without explanation. The ratio of microsomal protein to RNA (milligram protein/milligram RNA) ranged from 9.7 to 10.1 for the different treated groups. Recoveries of microsomal RNA compared with whole homogenate RNA were $21 \%, 24 \%, 26 \%$, and $24 \%$ for fed ad lib., 24,48 , and $72 \mathrm{hr}$ fasted groups, respectively.

Experiments in Table III demonstrate that pancreases obtained from fed rats incorporated greater amounts of L-phenylalanine ${ }^{14} \mathrm{C}$ into amylase than pancreases from fasted rats. After a $48 \mathrm{hr}$ fast, there was a $57 \%$ decrease in incorporation per milligram protein and a $41 \%$ decrease in incorporation per unit amylase activity. Amylase content as well as amounts of amylase applied to columns were approximately equal for fed and $48-\mathrm{hr}$ fasted rats $(28,000$ and $29,000 \mathrm{U} / \mathrm{g}$ pancreas $)$. Recoveries of amylase from total homogenate were similar for each group (60\% and 62). The final preparation of amylase had an enzyme specific activity of $17,000 \mathrm{U} / \mathrm{mg}$ protein and gave only one band on gel electrophoresis.

TABLE III

Incorporation of L-Phenylalanine $-{ }^{14} C$ into Pancreatic Amylase

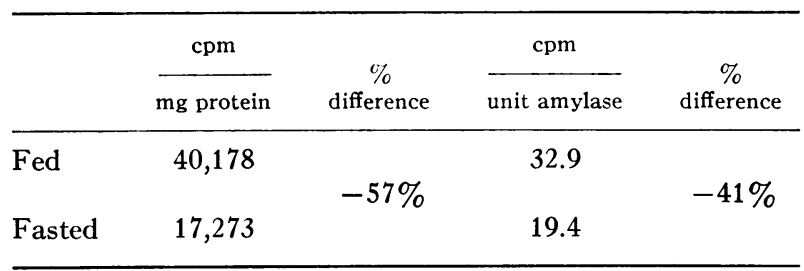

Pancreases obtained from rats fed ad lib. or fasted $48 \mathrm{hr}$ were used. The tissue was incubated in vitro under oxygen for $60 \mathrm{~min}$ at $37^{\circ} \mathrm{C}$, homogenized, and amylase isolated using column chromatography. $\mathrm{cpm} / \mathrm{mg}$ protein refers to radioactivity in amylase fraction; $\mathrm{cpm} /$ unit amylase refers to radioactivity in amylase fraction per unit amylase activity.
Table IV shows effects of fasting and feeding on Lphenylalanine ${ }^{14} \mathrm{C}$ incorporation in vitro by rat pancreatic microsomes. For these studies, microsomes and supernate prepared from fed or fasted animals were incubated in vitro. Factors necessary for in vitro protein synthesis were isolated in either the cell sap fraction (supernatant portion) or the particulate fraction (microsomal portion). By incubating supernate and microsomes in a determined order, one can obtain an indication of whether changes in rates of protein synthesis result from changes in either the particulate or supernatant fraction. Microsomes and supernate prepared from fed animals incorporated greater amounts of Lphenylalanine $-{ }^{14} \mathrm{C}$ than microsomes and supernate prepared from fasted animals $(44 \%)$. Microsomes from fed rats incubated with supernate from fasted rats incorporated $23 \%$ fewer counts than microsomes and supernate from fed rats. Likewise, microsomes and supernate from fasted rats incorporated fewer counts

TABLE IV

Effects of Fasting and Feeding on L-Phenylalanine- ${ }^{14} \mathrm{C}$ Incorporation In Vitro by Rat Pancreatic Microsomes

\begin{tabular}{llccc}
\hline Microsomes & Supernate & $\begin{array}{c}\mathrm{cpm} / \mathrm{mg} \\
\text { microsomal protein }\end{array}$ & $\begin{array}{c}\% \\
\text { difference }\end{array}$ & $P$ value \\
\hline Fed + Fed & $560 \pm 120$ & & \\
Fed + Fasted & $427 \pm 157$ & $+23.8 \%$ & $<0.05$ \\
Fasted + Fasted & $313 \pm 28$ & & \\
Fasted + Fed & $411 \pm 48$ & $+23.8 \%$ & $<0.01$
\end{tabular}

Values are means \pm SD (four experiments). Pancreatic microsomes prepared from rats fed or fasted $48 \mathrm{hr}$ were incubated in vitro with pooled supernatant fractions; energy-generating system and incorporation into TCA-insoluble material were determined. 
TABLE V

Relationship between Tissue Wet Weight, Protein, and DNA Content in Pancreas from Fed and Fasted Rats

\begin{tabular}{lrrr}
\hline & $\begin{array}{c}\text { mg tissue } \\
\text { wet weight }\end{array}$ & mg protein \\
\cline { 2 - 3 } & \multicolumn{1}{c}{ mg DNA } & & mg DNA \\
\hline Fed & $132.1 \pm 66$ & $14.7 \pm 1.4$ \\
Fasted $24 \mathrm{hr}$ & $133.6 \pm 58$ & $24.0 \pm 1.7$ \\
Fasted $48 \mathrm{hr}$ & $99.7 \pm 50$ & $13.3 \pm 0.3$ \\
Fasted $72 \mathrm{hr}$ & $80.9 \pm 36$ & $10.7 \pm 0.4$ \\
\hline
\end{tabular}

Values are means $\pm \mathrm{SE}$. Pancreas removed from fed or fasted rats, weighed on a Roller-Smith balance, minced, and homogenized. Protein and DNA determined as described in the Methods section.

than microsomes from fasted rats incubated with supernate from fed rats. This $23 \%$ greater incorporation in counts appeared to be due to ingredients present in the fed supernate. It seems in fed animals that enhancement of amino acid $-{ }^{14} \mathrm{C}$ incorporation into protein results from changes at both the microsomal as well as supernatant level. It is known that microsomes contain messenger RNA whereas cytoplasmic fractions contain activating enzyme, $t-R N A$, and transfer factors. Studies are being performed to determine which of these factors was responsible.

Table V shows relationships between tissue wet weight, protein, and DNA content of pancreas from fed and fasted rats. Tissue wet weight per milligram DNA was similar for fed and 24-hr fasted rats. Fasting 48 and $72 \mathrm{hr}$ was associated with $24 \%$ and $39 \%$ decreases in tissue wet weight. There was an initial increase in protein content per milligram DNA with fasting $24 \mathrm{hr}$ but a decrease thereafter (48 and $72 \mathrm{hr}$ ). Protein content per unit DNA was approximately equal in fed ad lib. and 48-hr fasted rats.

It was previously shown using pigeons that administration of analogues of the neurohormone, acetylcholine, was associated with enhancement of protein synthesis. If decreased protein synthesis in the pancreas after fasting were, in part, due to decreased neurohormonal stimulation of the pancreas, then administration of an analogue of the neurohormone, acetylcholine, should be associated with an increase in protein synthesis comparable to that observed in the fed animal. If, on the other hand, decreases in protein synthesis were due to "unknown dietary factors," then bethanechol chloride administration should not be associated with increased pancreatic protein synthesis. Fig. 2 shows rates of Lphenylalanine $-{ }^{14} \mathrm{C}$ incorporation into pancreatic tissue proteins by pancreases obtained from rats fasted $48 \mathrm{hr}$ and then given either saline or bethanechol chloride. Bethanechol chloride administration to rats fasted 48

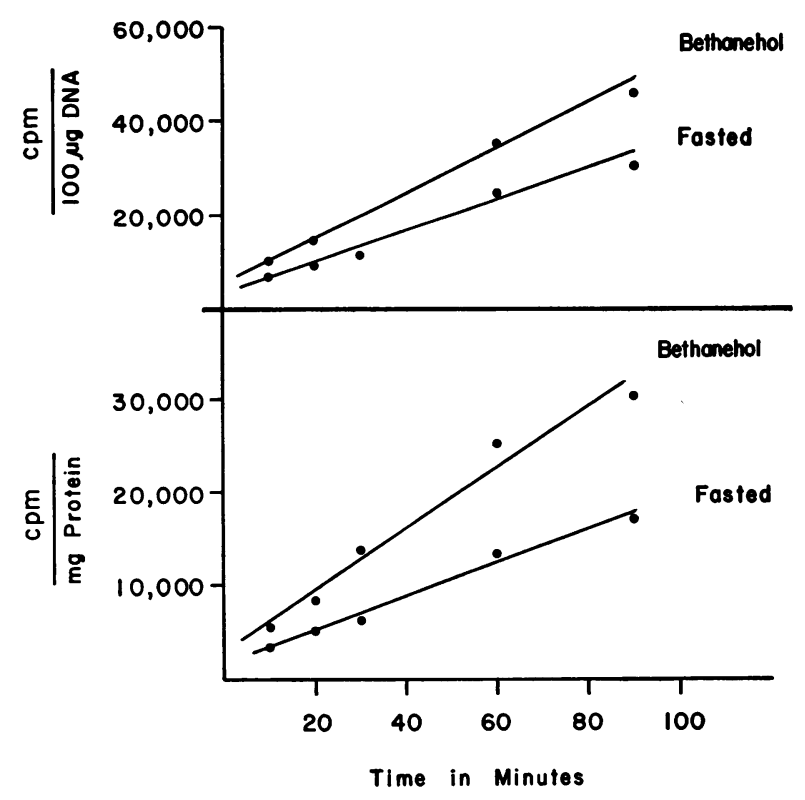

FIgURE 2 Rate of L-phenylalanine- ${ }^{14} \mathrm{C}$ incorporation by pancreas from rats fasted $48 \mathrm{hr}$ given bethanechol chloride 0.2 $\mathrm{mg} / \mathrm{kg}$ or saline s.c.

hr was clearly associated with a demonstrable increase in L-phenylalanine $-{ }^{14} \mathrm{C}$ incorporation whether the data were expressed in terms of protein or DNA. The difference in slopes of lines of the bethanechol-treated group most likely reflects secretory losses of protein.

The next series of experiments was designed to examine possibilities that changes in L-phenylalanine- ${ }^{14} \mathrm{C}$ incorporation observed with feeding or fasting might be due to changes in pool size or uptake of amino acids by the pancreatic acinar cell. Table VI shows content of L-phenylalanine per gram tissue wet weight in pancreases removed from fed or fasted $(24 \mathrm{hr})$ rats. Phenylalanine content was slightly greater in pancreases of fasted than fed rats. These values agree with values previously obtained for pigeon pancreas. L-Phenylalanine content of the incubating medium was $4800 \mu$ moles/ $\mathrm{ml}$ or about 100 times greater than the concentration of

\section{TABLE'VI}

L-Phenylalanine Content of Pancreases from Fed or Fasted Rats

\begin{tabular}{l}
\hline \\
\cline { 2 - 2 } \\
\hline Fed \\
Fasted $48 \mathrm{hr}$ \\
\hline tissue wet weight \\
\hline Pancreases from four fed or fasted rats were pooled, minced, \\
and homogenized in 1\% picric acid, and amino acid content \\
of the soluble portion was determined using amino acid \\
autoanalyzer.
\end{tabular}



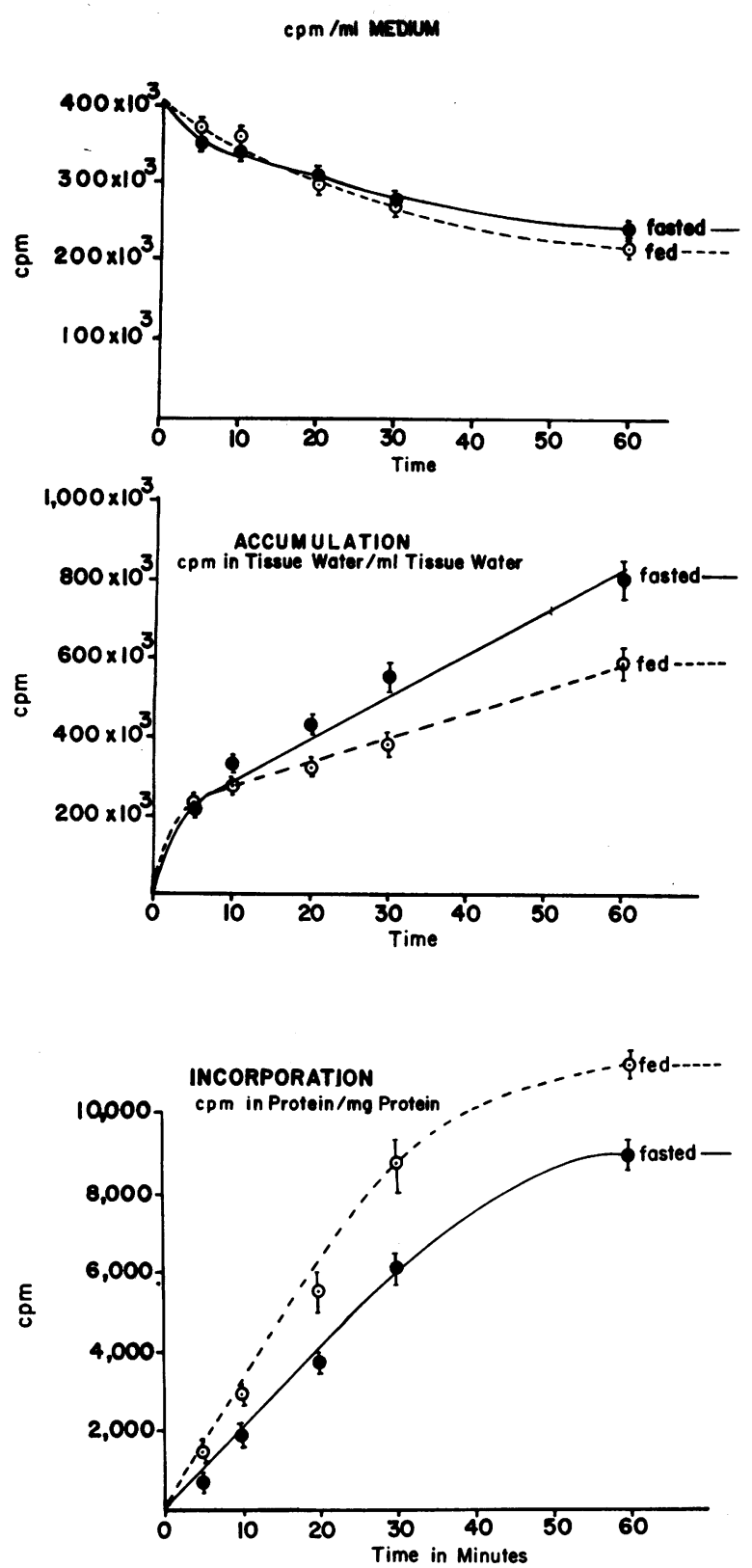

Figure 3 Pancreases from fed or fasted rats were incubated in vitro, and measurement of $\mathrm{L}$-phenylalanine- ${ }^{14} \mathrm{C}$ in media, tissue water, and protein was performed.

free L-phenylalanine in tissue water. Thus, if it were shown that intracellular concentrations of amino acids were rapidly diluted by amino acids in the medium, it would be highly unlikely that such minor differences could account for differences in L-phenylalanine $-{ }^{14} \mathrm{C}$ incorporation by pancreases from fed or fasted rats.

Fig. 3 shows data obtained when pancreases from fed and fasted rats were incubated $5,10,20,30$, and $60 \mathrm{~min}$ in vitro, and amounts of L-phenylalanine $-{ }^{14} \mathrm{C}$ in medium, tissue water, and protein were determined. After $60 \mathrm{~min}$ of in vitro incubation, the concentration of L-phenylalanine $-{ }^{14} \mathrm{C}$ in medium containing pancreases from fasted rats was greater than that of medium containing pancreases from fed rats. The concentration of L-phenylalanine- ${ }^{14} \mathrm{C}$ in tissue water of pancreases from fasted and fed rats was equal after 5 and $10 \mathrm{~min}$ of incubation, but after 20,30, and $60 \mathrm{~min}$ of incubation, the concentration of label was greater in tissue water of fasted rats. Rates of incorporation of L-phenylalanine${ }^{14} \mathrm{C}$ into protein were greater in fed than fasted rats for all periods of incubation. Recovery studies for these experiments demonstrated accountability of up to $98 \%$ of label in either the media, tissue water, or protein. In summary, these studies show greater disappearance of label from the medium and greater incorporation into protein by pancreases obtained from fed rats. There was also rapid equilibration of amino acids in medium with that in tissue water.

\section{DISCUSSION}

It has been well established that feeding, sham feeding, administration of cholecystokinin-pancreozymin, or cholinergic drugs results in initiation of secretion of pancreatic digestive enzymes (19). However, effects of such stimulation on pancreatic protein synthesis has been unclear. In fact, two somewhat opposing points of view have described the relationship between synthesis and secretion in the pancreas. One view suggested that after secretion there was synthesis of new product. The second view suggested that protein synthesis was constant, that secretion was inconstant or variable, and that variations in enzyme content resulted only from changes in secretion.

Reconciliation of these differing points of view has been provided by recent studies comparing effects of in vivo and in vitro administration of bethanechol chloride, cholecystokinin-pancreozymin, and cyclic AMP (20). In these studies, it was shown that administration of these agents in vivo was associated with initiation of both secretory and synthetic processes, whereas, administration of these agents in vitro was associated only with initiation of secretion. Clearly, both points of view are correct as related to the type of experimental model under study by the investigator.

However, the question of whether feeding and fasting are associated with differing rates of pancreatic digestive enzyme synthesis has not been resolved. Poort and Kramer recently published experiments in which they were unable to show differences in rates of incorporation of a ${ }^{14} \mathrm{C}$-labeled amino acid into tissue proteins by pancreases obtained from fed or fasted rats. These investigators concluded that pancreatic protein synthesis in the mammalian pancreas was constant and that feed- 
ing and fasting were not associated with changes in rates of pancreatic enzyme synthesis (8).

Their observations, utilizing rat pancreas, were at variance with experiments which had utilized pigeon pancreas. Pancreases from fed pigeons compared with pancreases from fasted pigeons demonstrated the following: greater incorporation of palmitate- ${ }^{14} \mathrm{C}$ into triglycerides and phospholipids, greater rates of oxidation of palmitate $-{ }^{14} \mathrm{C}$ to ${ }^{14} \mathrm{CO}_{2}$, greater rates of incorporation of uridine- ${ }^{3} \mathrm{H}$ into RNA, and greater rates of incorporation of $\mathrm{L}$-phenylalanine $-{ }^{14} \mathrm{C}$ into proteins (21-23).

The present studies have examined rates of amino acid- ${ }^{14} \mathrm{C}$ incorporation into tissue proteins, microsomal proteins, and amylase by pancreases obtained from rats which were fed ad lib. or fasted 24,48 , and $72 \mathrm{hr}$. The data show that pancreases from fed rats incorporated greater amounts of $\mathrm{L}$-phenylalanine $-{ }^{14} \mathrm{C}$ into tissue and microsomal protein than rats fasted 24,48 , or $72 \mathrm{hr}$. An enhancement of L-phenylalanine ${ }^{14} \mathrm{C}$ incorporation was demonstrated whether the data were expressed in terms of milligram protein or microgram DNA. Moreover, administration of bethanechol chloride, an analogue of acetylcholine, to rats fasted $48 \mathrm{hr}$ was associated with enhancement of $\mathrm{L}$-phenylalanine- ${ }^{14} \mathrm{C}$ incorporation into protein at rates almost equal to those seen in fed animals. When pancreatic amylase was isolated from fed rats, there was greater specific radioactivity of L-phenylalanine $-{ }^{14} \mathrm{C}$ per milligram protein as well as per unit amylase. In addition, pancreatic microsomes isolated from fed rats and incubated in vitro with an energygenerating system incorporated greater amounts of label than microsomes from fasted rats. Moreover, experiments incubating cell sap and microsomes in random order suggested that increases associated with feeding resulted from changes at ribosomal as well as cytoplasmic levels of control.

A number of possible sources of error have been eliminated by design of these experiments. Variations in accumulation of amino acids, an indication of transport, by pancreases from fasted or fed animals could not account for changes in incorporation since accumulation of L-phenylalanine $-{ }^{14} \mathrm{C}$ at $5-20 \mathrm{~min}$ was almost identical for tissue obtained from either fasted or fed rats.

Variations in pool size or tissue content of amino acids between fasted and fed animals could not account for increased incorporation of L-phenylalanine $-{ }^{14} \mathrm{C}$ into protein since pool sizes of phenylalanine were almost equal in pancreases from fed or fasted rats. Moreover, by studying incorporation in vitro, intracellular pools of amino acids were rapidly equilibrated with much higher concentrations of amino acids in the incubating media. Hanking and Roberts have shown that intracellular concentrations of amino acids in tissue slices rapidly equilibrate with that of the supporting media (24). There were almost linear increases in L-phenylalanine- ${ }^{1 \mathrm{C}} \mathrm{C}$ incorporation despite the rapid changes in concentration of $\mathrm{L}$-phenylalanine $-{ }^{14} \mathrm{C}$ in intracellular tissue water.

Another possible source of error might be due to secretory losses of pancreatic protein after feeding. In other words, could the apparent increase in incorporation result from decreases in milligrams protein of the tissue (a change in denominator rather than numerator)? However, protein content of pancreases obtained from animals fed ad lib. and animals fasted $48 \mathrm{hr}$ was almost equal. In addition, decreases in rates of incorporation with fasting were apparent whether the data were expressed in terms of DNA or protein. Moreover, it should be pointed out that although the pancreas secretes large amounts of enzyme when expressed in terms of enzyme activity, such activity reflects only minor changes in protein content of the entire gland. For example, 2000 $\mathrm{U}$ of amylase activity represents $1-1.5 \mathrm{mg}$ of protein. Secretory studies using rats have shown that maximal secretory rates obtained with in vivo pancreozymin or bethanechol elicit secretion of only $2-4 \mathrm{mg}$ protein $/ \mathrm{hr}$ (25). Such secretory losses of protein represent a small change compared with the total weight of the organ (2-4 $\mathrm{mg}$ protein vs. $750-1000 \mathrm{mg}$ tissue wet wt).

In vitro incubation of pancreas and isolation of microsomes from rats demonstrated 25,45 , and $60 \%$ decreased incorporation of $\mathrm{L}$-phenylalanine- ${ }^{14} \mathrm{C}$ into microsomal protein with 24,48 , and $72 \mathrm{hr}$ of fasting. These experiments, utilizing a short incubation period $(15 \mathrm{~min})$ as well as isolation of subcellular sites of protein synthesis (ribosomes), were performed to minimize effects of changes in pool size of product (protein), which might alter results. The results of these experiments agree with results obtained when L-phenylalanine- ${ }^{14} \mathrm{C}$ incorporation into whole tissue protein was examined.

Incubation of microsomes prepared from fed and fasted rats with an energy-generating system demonstrated fasting was associated with decreased amino acid- ${ }^{14} \mathrm{C}$ incorporation into microsomal protein. The data suggest that such changes result from alterations involving both microsomal and cytoplasmic components. Differences in amino acid-activating enzymes, t-RNA, and transfer enzymes ( $\mathrm{pH} 5$ fraction) may account for changes at the cytoplasmic level. Differences at the microsomal level may reflect programming of the ribosomes with messenger RNA. Studies are underway to better define these changes.

In conclusion, these investigations strengthen the view that pancreatic protein synthesis is a variable process and that augmentation of secretion is frequently associated with augmentation of synthesis. The precise manner whereby such control is maintained and integrated is unknown. Moreover, the role that such com- 
plex mechanisms of control may play in human disease remains undefined.

\section{ACKNOWLEDGMENTS}

We would like to acknowledge the technical assistance of Mrs. Marilyn LaSure and Mrs. Nancy Parks and the secretarial assistance of Mrs. Elizabeth Spainhour.

\section{REFERENCES}

1. Farber, E., and H. Sidransky. 1956. Changes in protein metabolism in the rat pancreas on stimulation. J. Biol. Chem. 222: 236.

2. Fernandes, J. F., and L. C. V. Junqueira. 1955. Protein and ribonucleic acid turnover rates related to activity of digestive enzymes of pigeon pancreas. Arch. Biochem. 55: 54 .

3. Webster, P. D. 1969. Effect of stimulation on pancreatic amylase secretion and nuclear RNA synthesis. Proc. Soc. Exp. Biol. Med. 132: 1072.

4. Webster, P. D., and M. P. Tyor. 1966. Effects of intravenous pancreozymin on amino acid incorporation in vitro by pancreatic tissue. Amer. J. Physiol. 211: 157.

5. Hokin, L. E., and M. R. Hokin. 1961. The synthesis and secretion of digestive enzymes by pancreas tissue in vitro. In The Exocrine Pancreas. A. V. S. deReuck and M. P. Cameron, editors. Little, Brown and Company, Boston. 186.

6. Dickman, S. R., R. L. Holtzer, and G. Gazzinelli. 1962. Protein synthesis by beef pancreas slices. Biochemistry. $1: 574$.

7. Schucker, R., and L. E. Hokin. 1954. The synthesis and secretion of lipase and ribonuclease by pigeon pancreas slices. J. Biol. Chem. 210: 551.

8. Poort, C., and M. F. Kramer. 1969. Effect of feeding on protein synthesis in mammalian pancreas. Gastroenterology. 57: 689.

9. Redman, C. M., P. Siekewitz, and C. E. Palade. 1966. Synthesis and transfer of amylase in pigeon pancreatic microsome. J. Biol. Chem. 241: 1150.

10. Spackman, D. H., W. H. Stein, and S. Moore. 1958. Automatic recording apparatus for use in the chromatography of amino acids. Anal. Chem. 30: 1190 .
11. Webster, P. D. 1968. Effect of methacholine on pancreatic amylase synthesis. Gastroenterology. 55: 375.

12. Gornall, A. G., C. J. Bardawill, and M. M. David. 1949. Determination of serum proteins by means of the biuret reaction. J. Biol. Chem. 177: 751.

13. Lowry, O. H., N. J. Rosebrough, A. L. Farr, and R. J. Randall. 1951. Protein measurement with the Folin phenol reagent. J. Biol. Chem. 193: 265.

14. Bernfeld, P. 1955. Amylases $\alpha$ and $\beta$. Methods Enzymol. $1: 149$.

15. Schneider, W. C. 1957. Determination of nucleic acids in tissues by pentose analysis. Methods Enzymol. 3:680.

16. Schmidt, G., and S. J. Tannhauser. 1945. A method for the determination of deoxyribonucleic acid, ribonucleic acid, and phosphoproteins in animal tissues. J. Biol. Chem. 161: 83.

17. Schneider, W. C. 1945. Phosphorus compounds in animal tissues. I. Extraction and estimation of desoxypentase nucleic acid and of pentose nucleic acid. J. Biol. Chem. 161: 293.

18. Volkin, E., and W. E. Cohn. 1954. Estimation of nucleic acids. Methods Biochem. Anal. 1: 287.

19. Dreiling, D. A., and H. D. Janowitz. 1961. The measurement of pancreatic secretory function. In The Exocrine Pancreas. A. V. S. deReuck and M. P. Cameron, editors. Little, Brown and Company, Boston. 225.

20. Morisset, J. A., and P. D. Webster. 1971. In vitro and in vivo effects of pancreozymin, urecholine, and cyclic AMP on rat pancreas. Amer. J. Physiol. 230: 202.

21. Webster, P. D., and M. P. Tyor. 1966. Effect of fasting and feeding on lipid metabolism of pigeon pancreas. Amer. J. Physiol. 210: 1076.

22. Webster, P. D., and M. P. Tyor. 1967. Effects of fasting and feeding on uridine ${ }^{8} \mathrm{H}$ incorporation into RNA by pancreas slices. Amer. J. Physiol. 212: 203.

23. Webster, P. D., and M. P. Tyor. 1966. Effect of intravenous pancreozymin on amino acid incorporation in vitro by pancreatic tissue. Amer. J. Physiol. 211: 157 .

24. Hanking, B. M., and S. Roberts. 1964. Influence of amino acid levels on protein synthesis in vitro. Nature (London). 204: 1194.

25. Leroy, J., J. A. Morisset, and P. D. Webster. 1971. Dose related response of pancreatic synthesis and secretion to cholecystokinin-pancreozymin. J. Lab. Clin. Med. 78: 149 . 